\title{
THE COST-PRODUCTION DUALITY APPROACH TO THE MEASUREMENT OF LABOUR PRODUCTIVITY: A DYNAMIC TOOL FOR EFFECTIVE HUMAN RESOURCE MANAGEMENT
}

\author{
G VAN ZYL \\ Professor in Economics \\ Department of Economics \\ Rand Afrikaans University
}

\begin{abstract}
Positive real increases in the prices of inputs, as the result of an inefficient level of productivity, can no longer be accepted in competitive markets. The survival and more specifically the competitiveness of businesses and industries is critically dependent on a higher level of cost efficiency and in particular a more productive input base. The aim of the paper is to present the methodology, structure and results of a new dual cost-production instrument where changes in the level of labour productivity can be measured. A scientific derived and well-tested instrument is developed. This instrument should enable human resource managers to monitor productivity changes more effectively and make timely decisions on ways and means that could improve the productivity of labour.
\end{abstract}

\section{OPSOMMING}

Positiewe reële toenames in die pryse van insette as die resultaat van 'n oneffektiewe vlak van produktiwiteit kan nie langer in mededingende markte geduld word nie. Die oorlewing en meer spesifiek die mededingendheid van ondernemings en industrieë is krities afhanklik van 'n hoër vlak van koste-doelmatigheid en in die besonder van ' $n$ meer produktiewe inset basis.

Die doel van die publikasie is om die metodiek, struktuur en resultate van 'n nuwe gelyktydige koste-produksie instrument bekend te stel waarmee veranderinge in die vlak van arbeidsproduktiwiteit gemeet kan word. 'n Wetenskaplik-afgeleide en getoetste instrument is ontwikkel. Diè instrument behoort personeelpraktisyns in staat te stel om produktiwiteitsveranderinge meer effektief te kan monitor en gevolglik tydige besluite te kan neem oor wyses waarop arbeidsproduktiwiteit verbeter kan word.

The aim of this paper is to present the methodology, structure and results of a dual cost-production model where changes in the level of labour productivity of a firm and an industry can be measured. The analysis is based on the application of the principles of duality where co-integrated production functions for each sample time series are derived from dual cost functions in order to derive the marginal efficiency coefficients which measures productivity changes. The South African motor vehicle manufacturing industry is used as a case study.

A decision had to be made whether to estimate a more flexible or a more restricted form of a production function for each chosen time series. A more restrictive form was chosen because it is assumed to be more stable and robust than a flexible form and is thus more suitable for incorporation into a production model, which is utilised for the purpose of this particular analysis (Wynn 1974).

\section{THE DUAL COST FUNCTION}

The optimal value of the objective function of the primal problem is equal to the optimal value of the corresponding dual problem. Optimal economic behaviour of business entities is most commonly measured by the principles of profit maximisation and the principle of cost minimisation. The principle of the duality theorem thus states that any constrained profit maximisation problem has a dual problem in constrained minimisation of cost (Salvatore 1996).

The maximum production output level is normally expressed as a function of the input base and a certain level of technological know-how (the result of economies of scope and the learning curve effect). In terms of duality principles the minimum cost function can be expressed as a function

Requests for copies should be addressed to: $G$ van Zyl, Department of Economics, RAU University, PO Box 524, Auckland Park, 2006 of the combined production output of the firm or industries, the input base, the input prices and the given level of technological know-how. The applicable average cost function is defined as the minimum cost level divided by the given level of manufacturing output. The applicable average cost function is important in determining returns to scale for the purpose of the compilation of the dual model (Hirschey 1995)

The cost minimisation problem is expressed as a constrained optimisation problem where minimum cost is expressed as the sum of input prices plus a Lagrange multiplier times the difference between the levels of production output on the one hand and the levels of inputs and technical know-how on the other hand. The first order conditions for the minimisation of production cost are simply the partial derivatives of the minimum cost function in terms of 1) input prices and 2) the difference between manufacturing output and the level of inputs and technological know-how. The cost function dual to the production function is determined by substituting each level of input combination into the first order derivative of the difference between manufacturing output and the level of inputs and technological know-how. The optimal levels of inputs are substituted into the cost equation (expressed as the sum of the product of the level of inputs and input prices).

\section{THE PROPERTIES OF THE DATA USED IN THE ESTIMATION}

An important aspect of data collection is to establish the properties of each data set by analysing each data series thoroughly. Properties such as stationarity or the order of integration are important.

The following time series are used in the estimation of cost functions for the different sample time series and the consequent derivation of the production functions: 
1. The cost of production is expressed as cost of labour plus the cost of capital.

The cost of capital is calculated as real capital stock multiplied by real user cost of capital. The user cost of capital is calculated in such a way that it not only includes the acquisition cost of capital but also the return forgone by using capital rather than renting it, depreciation and any capital gains/losses associated with holding the particular type of capital (Maurice 1985). For the purposes of the estimations the user cost is expressed as: user cost of capital $=q_{k}(i+\delta)$; where $q_{k}$ is the acquisition cost of capital stock, $i$ the real rate of interest and $\mathrm{d}$ the rate of depreciation. The acquisition cost of capital is deflated by the production price index in order to account for differences in the price level at the time of acquisition. The time series is transformed to its logarithmic form.

The cost of labour for each time period is calculated as labour employed times the real cost of labour. The real cost of labour is calculated as the total wages \& salaries paid deflated by the production price index. The time series is transformed to its logarithmic form.

After the cost of production is calculated, the time series is transformed into its logarithmic form.

2. Manufacturing output at real cost

The manufacturing output at factor cost time series is simply transformed into its logarithmic form.

3. A technology know-how index

This index is included in the function in order to capture changes in technological know-how. The index is expressed as a function of a socio-education index, an energy index and a labour skills index for the industry. The weight of each of the series in this equation is derived by performing a linear regression of the three indices in the equation on manufacturing output. The estimated coefficients are then used as an indication of the relative importance of each series in the technology index. The ultimate choice of the explanatory indices is based on their substantial influence on the efficiency of manufacturing production. This index is not transformed into its logarithmic form.

4. The demand for labour

This variable is represented by a time series of workers employed in the manufacturing industries per time period. Each time series is transformed into its logarithmic form.

5. Real fixed capital stock

This variable is represented by a time series of real fixed capital stock per time period in the manufacturing industries. The time series is transformed to its logarithmic form.

6. Dummy variables

The aim of the dummy variables is to avoid bias in the estimation. Dummy variables are introduced to firstly cover the period 1982-1993 when it became difficult to import capital stock (as a result to exogenous political restrictions) and secondly to cater for tense labour relations in the period 1987-2001 that resulted in strikes and work stoppages.

7. All the data series are tested for stationarity and the level of integration of each of the variables in the regression for each time period. The tests are performed on the data in their logarithmic form. All variables are tested at 5\% level of significance and all the variables are integrated of the order of 1 .

\section{THE EMPIRICAL ESTIMATION OF COST FUNCTIONS}

The empirical function for the cost of production in the industry for each time period is expressed as:

Cost of production $=\mathrm{f}$ (Production output, user cost of capital, real cost of labour, technological know-how index)

The methodology that is used to estimate the cost functions is to apply a roll-up approach where the first data point of the previous data series is omitted and where a new data point is chosen in a sequential manner for each successive data series. The long-run coefficients of the cost functions are then estimated using ordinary least squares. These functions are estimated with a restriction on the coefficients of the input prices to sum to unity. The restriction follows from economic theory that states that a cost function must be homogeneous of degree 1 in prices, that is, by doubling prices costs should be doubled (Maurice 1985:135).

The resulting coefficients of the cost estimation per time period are summarized in Table 1:

TABLE 1

ESTIMATION RESULTS OF THE CO-INTEGRATION COST EQUATION PER TIME PERIOD

\begin{tabular}{llll}
\hline Independent variable & $\begin{array}{l}\text { Coefficients } \\
1975-1999\end{array}$ & $\begin{array}{l}\text { Coefficients } \\
1976-2000\end{array}$ & $\begin{array}{l}\text { Coefficients } \\
1977-2001\end{array}$ \\
\hline Production output (est (1)) & 0.64210 & 0.61230 & 0.5960 \\
User cost of capital (est (2)) & 0.38120 & 0.39340 & 0.4188 \\
Real cost of labour (est (3)) & 0.61880 & 0.62960 & 0.6452 \\
Technology index (est (4)) & -0.45912 & -0.4788 & -0.4890 \\
$\mathrm{R}^{2}$ & 0.9231 & 0.9324 & 0.9245 \\
Adjusted $\mathrm{R}^{2}$ & 0.9001 & 0.9133 & 0.9167 \\
\hline
\end{tabular}

Dependent variable: Cost of production

Source: Own estimations

The long-run co-integrated cost functions for each time period are as follow:

- 1975 - 1999

Cost of production $=0.64210^{*}$ Manufacturing output + $0.38120^{*}$ user cost of capital $+0.61880 *$ real cost of labour 0.45912 * technological know-how index

- $1976-2000$

Cost of production $=0.61230 *$ Manufacturing output + $0.39340^{*}$ user cost of capital

+0.62960 * real cost of labour $-0.4788^{*}$ technological knowhow index

- $1977-2001$

Cost of production $=0.5960^{*}$ Manufacturing output + $0.4188^{*}$ user cost of capital

$+0.6452{ }^{*}$ real cost of labour $-0.4890^{*}$ technological knowhow index

The co-integrated cost functions have economic significance in the sense that the signs of the estimated coefficients are as expected. The magnitude of the estimated manufacturing output parameter represents a decreasing degree of decreasing returns to scale.

The residuals of the estimated cost function are tested for stationarity. Econometric tests are used to test whether the residuals obtained from the estimated production cost regressions are stationary (Makridakis 1998). These tests confirm that the residuals are stationary at a $5 \%$ level of significance. The error terms of the regressions co- 
integrated and are confirmed by a correlogram test on the residuals. The conclusion is that these estimated cost functions could be used to derive long-run co-integrated production functions in order to establish the changes in the marginal efficiencies of the inputs and more specifically labour productivity.

\section{THE DERIVATION OF CO-INTEGRATED PRODUCTION FUNCTIONS}

By applying duality theory it is possible to derive production functions from the estimated cost functions. The derivation of the long-run production functions is based on the methodology and calculations of Berndt (1991). From the estimated cost equations it follows that production costs always increases (as indicated by the estimated cost function) and therefore technology in this particular industry displays decreasing returns to scale. This result was confirmed by using the duality methodology and calculations of Berndt (1991). The calculation for returns to scale is expressed as:

$$
r=1 / 1+e s t(1)
$$

(where $r$ is the returns to scale and est(1) is the estimated coefficient of production output in the cost function).

The estimated returns to scale coefficient for each data series is indicated in the following Table 2.

TABLE 2

Returns to SCALE COEFFICIENT PER TIME PERIOD

\begin{tabular}{lc}
\hline Time period & Returns to scale coefficient \\
\hline $1975-1999$ & $\frac{1}{1.64210}=0.6090$ \\
$1976-2000$ & $\frac{1}{1.6123}=0.6202$ \\
$1977-2001$ & $\frac{1}{1.5960}=0.6266$ \\
\hline
\end{tabular}

Source: Own calculations

By simply multiplying each of the input price coefficients and that of technology by returns to scale (r), the coefficients of the inputs $(\mathrm{a}, \mathrm{b}$ and $\mathrm{d})$ in the production function (production output $=a K^{\alpha} L^{\beta} \operatorname{tei}^{\delta} \delta$ ) are obtained. These calculations are based on the principles of duality and are as follows:

$$
\begin{aligned}
& \alpha=\operatorname{est}(2){ }^{*} \mathrm{r} \quad(\operatorname{est}(2)=\text { coefficient user cost of capital) } \\
& \beta=(1-\operatorname{est}(3)){ }^{*} \mathrm{r} \quad(\operatorname{est}(3)=\text { coefficient for labour cost }) \\
& \delta=\operatorname{est}(4){ }^{*} \mathrm{r}(\operatorname{est}(4)=\text { coefficient for the technology index) }
\end{aligned}
$$

The associated constant for the production function is estimated simply by estimating an equation with the calculated coefficients, multiplied with the associated production variables, and a constant as an explanatory variable. The result of the least square estimation is a value for the unknown constant which can be used in the long-run cointegration equation. The calculated coefficients of the inputs $(\alpha, \beta$, and $\delta$ ) based on the principles of duality are indicated in the Table 3 .
TABLE 3

Calculated values for the PRODUCtion coefficients

\begin{tabular}{cccc}
\hline Time period & $\alpha$ & $\beta$ & $\delta$ \\
\hline $1975-1999$ & 0.2322 & 0.3768 & 0.2796 \\
$1976-2000$ & 0.2440 & 0.3905 & 0.2970 \\
$1977-2001$ & 0.2624 & 0.4043 & 0.3064 \\
\hline
\end{tabular}

Source: Own calculations

The co-integration production functions when the variables are not used in their logarithmic form are thus:

- 1975 - 1999

Manufacturing output $=8.0154{ }^{*}$ real fixed capital 0.2320 demand for labour 0.3768 tei 0.2798

- $1976-2000$

Manufacturing output $=8.7345^{*}$ real fixed capital 0.2440 demand for labour 0.3905 tei 0.2970

- 1977 - 2001

Manufacturing output $=9.3466^{*}$ real fixed capital 0.2624 demand for labour 0.4043 tei 0.3064

The successful derivation of the production functions is clearly illustrated by acceptable root mean squared errors, mean absolute errors and mean absolute percentage errors. Dynamic simulations were performed on the long-run cointegrated production functions as an indication of the goodness of fit of the model. From the dynamic simulations the assumption can be made that each of the estimated production functions delivers a very satisfactory fit and is a stable function.

\section{THE MEASUREMENT OF CHANGES IN THE LEVEL OF PRODUCTIVITY}

The changes in the marginal efficiencies (productivity) of the various components of the input base are simply calculated as the percentage increase or decrease in the marginal products of these components ( $a, b$, and d) over the specified sample periods.

$\Delta^{\mathrm{e}}$ in capital efficiency (productivity) $=\frac{\alpha_{t+1}-\alpha_{t}}{\alpha_{t}} x \frac{100}{1}$

$\Delta^{\mathrm{e}}$ in labour efficiency (productivity) $=\frac{\beta_{t+1}-\beta_{t}}{\beta_{t}} \times \frac{100}{1}$

$\Delta$ in technology efficiency (productivity) $=\frac{\delta_{t+1}-\delta_{t}}{\delta_{t}} \times \frac{100}{1}$

The results of these calculations are summarized in Table 4 .

TABLE 4

Percentage changes in the efficiency estimates

\begin{tabular}{lccc}
\hline Time period & $\alpha$ & $\beta$ & $\delta$ \\
\hline $1975-1999$ & +5.082 & +3.640 & +6.220 \\
to & & & \\
$1976-2000$ & & & \\
$1976-2000$ & +7.540 & +3.530 & +3.1650 \\
to & & & \\
$1977-2001$ & & & \\
\hline
\end{tabular}

Source: Own calculations 
Positive percentage increases in the marginal efficiencies of all the inputs contributed to the improvement in the returns to scale of the industry. It is also clear from Table 4 that the improvement in labour productivity is the lowest of all the inputs and that capital is substantially more efficient (productive) than the labour input.

The optimal combination of inputs is an important consideration for a firm/industry. The estimated efficiency criterion coefficient $(\psi)$ enables the decision maker to determine the required changes in input combinations in order to strive for a more optimal (efficient) input base. The results of the calculations on the optimality coefficient $(\psi)$ are summarized in Table 5 (the improvement in the level of technology is taken as a given).

TABLE 5

OPTIMALITY OF THE INPUT BASE

\begin{tabular}{cc}
\hline Sample period & $\begin{array}{c}\text { Optimality coefficient } \\
\psi=\beta(\mathrm{K} / \mathrm{L})-\alpha(\mathbf{w} / \mathbf{r})\end{array}$ \\
\hline $1974-1999$ & -8.215 \\
$1975-2000$ & -7.312 \\
$1976-2001$ & -7.115 \\
\hline
\end{tabular}

Source: Own calculations

From the Table 5 it is clear that in each of the sample periods the optimality coefficient clearly indicates an over-utilisation of labour (albeit at a slower pace). This implies that the greater level of capital efficiency combined with a likely increase in capital stock could push the input mix to a more optimal level. The message to human resource management is clear namely that labour productivity in this particular industry must increase substantially in order to avoid greater levels of capital substitution for the labour input.

\section{CONCLUSION}

A scientific derived and well tested instrument in a managerial, econometric and statistical sense was developed. The instrument measures the changes in the level of productivity of the input base more accurately. It can easily be applied on firm level over weekly and/or monthly sample periods. This instrument should enable management to monitor productivity changes more effectively and make timely decisions that should result in a more optimal usage of resources.

\section{REFERENCES}

Berndt, E.R. (1991). The Practice of Econometrics; Classic and Contemporary. New York: Addison-Wesley.

Hirschey, M \& Pappas J.L. (1996). Managerial Economics. Orlando: Dryden Press.

Maurice, S.C. \& Smithson S.W. (1985). Managerial Economics; Applied Microeconomics for Decision Making. Homewood: Irwin.

Salvatore, D. (1996). Managerial Economics in a Global Economy. New York: McGraw-Hill.

Wynn R.F. \& Holden K. (1974). An Introduction to Applied Econometric Analysis. New York: Wiley \& Sons. 